\title{
BEYOND THE NATION: THE MOBILITY OF INDIAN LITERATURE ${ }^{1}$

\author{
BILL ASHCROFT \\ University of New South Wales \\ b.ashcroft@unsw.edu.au
}

Received: 18-09-2013

Accepted: 20-11-2013

\begin{abstract}
This paper argues that while it is generally accepted that contemporary Indian literature entered a decisive, cosmopolitan and globally popular phase with the publication of Midnight's Children in 1981, this period actually demonstrated a continuation of deep skepticism about nationalism that had originated with Rabindranath Tagore and Mahatma Gandhi. The three decades after 1981 have revealed a literature whose mobility and energy has had perhaps a greater impact on English literature than any other. The argument is that this mobility goes hand in hand with skepticism about nation and nationalism that has had a pronounced impact on the perception of the globalization of literature. Arundhati Roy's The God of Small Things (1997), Kiran Desai's The Inheritance of Loss (2006), Aravind Adiga's The White Tiger (2008) and Hari Kunzru's Transmission (2004) sketch the trajectory of the contemporary novel's extension of Midnight Children's subversion of the grand narrative of nation. Three of these share the status of Rushdie's novel as a Booker Prize winner and indicating that the impact of India's nationalist skepticism has been felt globally.
\end{abstract}

KEYWORDS: Indian literature; nationalism; globalization; mobility; Arundhati Roy; Kiran Desai; Aravind Adiga; Hari Kunzru

RESUMEN Más allá de la nación: la movilidad de la literatura india Partiendo de la aceptación generalizada de que la publicación de Midnight's Children en 1981 anunció la entrada de la literatura india contemporánea en una fase decisiva, cosmopolita y popular a nivel mundial, este artículo sostiene que este nuevo período literario debe considerarse una continuación de un escepticismo profundo hacia el nacionalismo cuyos orígenes residen en Rabindranath Tagore y Mahatma Gandhi. Durante las tres décadas transcurridas después de 1981, ha surgido una literatura cuya movilidad y energía posiblemente haya ejercido un impacto más significativo en la literatura en lengua inglesa que en cualquier otra literatura en otra lengua. La justificación de este artículo se basa en el hecho de que tal movilidad no puede separarse del escepticismo hacia la nación y el nacionalismo y que tal susceptibilidad es lo que ha determinado la actual percepción de la globalización de la literatura. The God of Small Things (1997) de Arundhati Roy, The Inheritance of Loss (2006) de Kiran Desai, The White Tiger (2008) de Aravind Adiga y Transmission (2004) de Hari Kunzru esbozan la trayectoria de la novela contemporánea en su condición de prolongación subversiva de la gran narrativa de la nación

\footnotetext{
${ }^{1}$ An earlier version of this paper was published as "Re-Writing India" in Krishna Sen \& Rituparna Roy (eds) (2013), Writing India Anew, Amsterdam: Amsterdam UP.
} 
iniciada por Midnight Children. Tres de estas novelas comparten con Rushdie el estatus de haber ganado el premio Booker, lo cual indica que el impacto del escepticismo nacionalista indio se ha experimentado a nivel global.

PALABRAS ClaVE: Literatura india; nationalismo; globalización; movilidad; Arundhati Roy; Kiran Desai; Aravind Adiga; Hari Kunzru.

For most critics, and possibly for most readers, contemporary Indian literature entered a decisive, cosmopolitan and globally popular phase with the publication of Salman Rushdie's Midnight's Children in 1981. The following decades have witnessed the growth of a literature that has been outward-looking, confident and increasingly widely read. It is arguable that in that time the Indian literary diaspora has had a greater impact on English Literature than writing from any other nation. The revolution inaugurated by Rushdie hinged on the subversion of the nationalist euphoria of midnight, 27 August 1947. One version of this story is that the euphoria continued until the arrival of Indira Gandhi, when disappointment set in with a vengeance. The 1980s saw the flourishing of a literature - particularly the Bombay novel (Ashcroft, 2011) - virtually obsessed with Gandhian corruption. But whatever the confluence of forces, it seems that Midnight's Children triggered scepticism about nationalism that has characterised India's increasingly vital and outward- moving literature.

However, in many respects the 'Rushdie revolution' represents a continuation rather than a break. While it is clear that Midnight's Children marks the beginning of the growth of diasporic Indian literature over the next three decades, it regenerates a hidden tradition of anti-nationalist utopianism in Indian literature most prominent in the writings Rabindranath Tagore and Mohandas Gandhi. The irony of this is that both Tagore and Gandhi have become nationalist icons and in Gandhi's case sanctified almost as a national deity. Yet it is their insurgent anti-national philosophy that best survives in the contemporary novel. Midnight's Children won the Booker Prize in 1981 and we can follow this phenomenon of post-nationalist mobility through subsequent Indian Booker Prize winners, the inheritors of Rushdie's prize-winning revolution, to understand the nature of this globalizing trend. The three Booker-winning novels are Arundhati Roy's The God of Small Things (1997), Kiran Desai's The Inheritance of Loss (2006) and Aravind Adiga's The White Tiger (2008). Also of key relevance here is a novel that 
perhaps more than any others demonstrates the direction of Indian writing: diasporic British Indian Hari Kunzru's Transmission (2004).

To understand the manner in which India is being written anew today, we need to understand the history of the Indian relationship with the idea of nation, in particular the history of its literary imaginings, undergirded by a utopianism that goes hand in hand, ironically, with a deep anti-nationalist scepticism. For both Tagore and Gandhi future thinking was inextricable from a sense of moral purpose in which Indian destiny existed beyond the confines of the Nation, and in many respects that utopian supra-nationalist vision of India came into full flower in the period inaugurated by Midnight's Children.

The imagined community of the Indian nation can be understood in three stages in India's literary development. Of course they are not clearly demarcated periods: they overlap extensively, but each is dominated by a particular utopian vision. The first period, from the beginning of the century to independence, is the time of nationalist fervour, of the light on the hill, the promised utopia of the modern Indian nation. This is the period in which Tagore's vision went against the grain of Swadeshi nationalism - two poles around which Indian writing continued to circulate. This is also the period in which Gandhi's Hind Swaraj came out in English, but the effect of Gandhi's deep scepticism about nationalism was not to take effect until after independence. The second is the period after independence, a period of apparent modernization but one that in reality consolidated the alternative modernity that had begun during colonial occupation. This is the period of national triumph in which Gandhi's vision of Hind Swaraj, although co-opted by official nationalist politics, proved to be subversive in the purity of its philosophical anarchism. The third stems from the time of Indira Gandhi - a manifestation of the imagined community for which Midnight's Children if not its initiator, is its most evocative example. This is a period of rebellion and recovery, but it moves by the turn of the century into a period of global optimism. In each one of these periods the figure of Mohandas Gandhi looms large but his presence underpins the imagining of the nation in quite different ways.

The nation-state has been critiqued in postcolonial analysis largely because the postindependence, post-colonized nation, that wonderful utopian idea, proved to be a focus of 
exclusion and division rather than unity, perpetuating the class divisions of the colonial state rather than liberating national subjects. However, nationalism and its vision of a liberated nation have still been extremely important to anti-colonial literature because the idea of nation has so clearly focused the utopian ideals of independence, and perhaps nowhere more so than in the early decades of twentieth-century India. Nevertheless, in Tagore we find the trenchant position of the earliest and most widely known antinationalist. For Tagore, there can be no good nationalism; it can only be what he calls the "fierce self-idolatry of nation-worship" (Tagore, 2005: 39) - the exquisite irony being the use of his songs as Bengali, Bangladeshi and Indian national anthems. Tagore's warning against the model of European nationalism was unmistakable:

This abstract being, the Nation, is ruling India. (46)

The Nation, with all its paraphernalia of power and prosperity... cannot hide the fact that the Nation is the greatest evil for the Nation. (60)

Nationalism is a great menace. It is a particular thing which for years has been at the bottom of India's troubles. (87)

Tagore's scepticism over nationalism was a by-product of his utopian vision. He railed against the teaching that "idolatry of the Nation is almost better than reverence for God or humanity." (83) Tagore's utopianism is nowhere more evident than in his belief in the spiritual potential of human society for openness and acceptance:

I have no hesitation in saying that those who are gifted with the moral power of love and vision of spiritual unity, who have the least feeling of enmity against aliens, and the sympathetic insight to place themselves in the position of others, will be the fittest to take their permanent place in the age that is lying before us. (78)

It is certainly not the spiritual fervour of this that characterizes contemporary Indian writing, but rather the sense of a future world beyond the restrictions of the nation. Indian society has always been exogenous and this has only become more pronounced.

Tagore was ahead of his time in more ways than one. However, the early years of the century were marked by an anti-colonial momentum that set very great store by the idea of the nation. Bankim Chandra Chatterjee's Anandamath coined the image that was to become the essence of Indian nationalism:

"an enchanting image more beautiful or glorious than Lakshmi or Sarasvati" "Who is she?" 
"The Mother"

"Who is this Mother?"

The monk answered: "She whose children we are." (Chatterjee, 2006: 149)

Mother India became a rallying point for Indian nationalism, and its most iconic representation in the film Mother India ensured that the image would continue to haunt the Indian imagination. Such images offer a much more powerful focus than 'visions of spiritual unity', and the connection between the nation and Mother India was imprinted on the Indian psyche. Yet, against the militancy of 'Swadeshi' nationalism Tagore produced his novel Ghare Baire (The Home and the World). Swadeshi advocated the boycott of foreign goods but "drew increasingly on the rhetoric and iconography of a revivalist Hindu nationalism that sought to define the nation in religious terms" (Gopal, 2009: 34). When Hindu-Muslim riots broke out Tagore became one of the movement's most trenchant critics, earning himself the reputation of apologist for colonialism. The complexity of utopian thinking can be seen in the clash between Mother India and Tagore's vision of a union of home and world. Both are visions of the future, one attaining tremendous power in the lead-up to independence, the other looking beyond the boundaries of nation and rejecting its idolatry. The latter is arguably the deeper and longer-lasting in the Indian literary consciousness.

In the decades before and after the turn of the century Indian writing has taken a significant turn - one affected by globalization, with its increasing mobility and its diasporic movements of people - that might be cautiously termed cosmopolitan, despite Tagore's reference to the "colourless vagueness" of the term (2005: 39). India has led the way in its literature, not only because of the proliferation of South Asian diasporic writing, but also because India itself has put the traditional idea of the nation as imagined community into question. Where did this questioning come from? When Gandhi wrote as early as 1909 that India's freedom struggle had misunderstood the "real significance" of Swaraj by equating it with independence, declaring: "My life henceforth is dedicated [to realizing its true meaning]", (Collected Works of Mahatma Gandhi [CWMG] 10:64, Hind Swaraj, 22 November 1909) he introduced a range of ideas centring on the concept of satyagraha that had little to do with conventional nationalism. Whereas independence meant outward freedom, Gandhi's goal was a deeper one that came, in time, to clash with conventional nationalist ideals: "The outward freedom therefore that we shall attain will 
only be in exact proportion to the inward freedom to which we may have grown at a given moment" (CWMG 38: 1-2, 1 November 1928).

Although Salman Rushdie admits to learning 'a trick or two' from G.V. Desani's All about H. Hatterr (1949), Midnight's Children (1981) can be regarded as the founding text of a new generation. The style of Rushdie's prodigious and excessive chronicle is continued in Alan Sealy's The Trotter-Nama (1990). However, in the main this new generation was characterised by mobility and hybridity and gained worldwide attention through writing from what might called the 'third-wave' diaspora. It was also characterised by a deep distrust of the boundaries of the nation, a distrust embodied in Saleem's despair. Nonetheless, Rushdie's novel had a different, more utopian vision, as he explains in Imaginary Homelands

What I tried to do was to set up a tension in [Midnight's Children], a paradoxical opposition between the form and content of the narrative. The story of Saleem does indeed lead him to despair. But the story is told in a manner designed to echo, as closely as my abilities allowed, the Indian talent for non-stop self-regeneration. This is why the narrative constantly throws up new stories, why it "teems." The form - multitudinous, hinting at the infinite possibilities of the country - is the optimistic counterweight to Saleem's personal tragedy. (Rushdie, 1991: 16)

Saleem's personal tragedy is of course the tragedy of the postcolonial nation. But it is also the tragedy of the idea of the bordered nation itself, the very concept of a bounded space within which a diverse people could come together as one. The saving grace, for Rushdie, is the capacity of a people to 'teem,' its irrepressible and exorbitant capacity to transcend the nation that becomes its most hopeful gesture. The rich underpinning of mythic allegory allows him to conceive a multitudinous civilizational reality existing beyond the nation. This is precisely the function of the Midnight's Children themselves: to reveal the improbability of the nation ever encompassing their extravagant variety and potential. This potential is one we could call utopian in the very unbounded extent of its possibilities.

The infinite possibilities of the country greatly exceed any notion of 'unity in diversity,' which is a standard, if deceptive national mantra. Rushdie is, in effect, describing a condition suggested by Jean Franco when she pointed out the inadequacy of Fredric Jameson's notorious designation of Third World literature as 'national allegories' (Franco, 1986: 69). Rather, we find "the dissolution of the idea of nation and the 
continuous persistence of national concerns" (211). Writing in the decade ushered in by Midnight's Children Franco could say that the nation "is no longer the inevitable frame for political or cultural projects" (204).

The response of nation-states the world over to the increasing global flow of people has been to make these borders ever more impermeable, and their actual ephemerality is shown nowhere more powerfully than in Amitav Ghosh's The Shadow Lines (1988). Although it was published in the 1980s, this book's devastating denunciation of nationalism and national borders, and its multi-layered narrative of memory and identity, continue to resonate in a world in which borders articulate a worldwide territorial paranoia. It stands as a powerful prelude to the present century, in its view of the great deception of nationalism and the illusory nature of borders. In an interview Ghosh remarked:

Today nationalism, once conceived of as a form of freedom, is really destroying our world. It's destroying the forms of ordinary life that many people know. The nation-state prevents the development of free exchange between peoples. (cited in Wassef, 1998: 75)

This is the classic postcolonial critique. Postcolonial nationalism, which is born in the quest for freedom, comes to imprison rather than liberate because it inherits its model of governance from the colonial state. However illusory and arbitrarily established the borders of the state may be, they come to function as rigid constructors of identity.

Ghosh continues Rushdie's satire of nationalism with a scathing dismantling of the concept of borders, not only geographical ones but also the borders of identity itself. The story of The Shadow Lines is woven around the ambivalent metaphors of maps, place, memory, nation and identity and the possibility of freedom from the borders they invoke. Every representation of space in the novel - rooms, houses, neighbourhoods, cities, countries - assumes a metonymic significance culminating in the importance of maps as metaphors of identity because they so clearly locate subjects (Mukherjee, 2006: 260). However, maps are also a metonym for the futile regulation of memory. As Robi says at the end of the book, "Why don't they draw thousands of little lines though the whole subcontinent and give every little place a new name? What would it change? It's a mirage; the whole thing is a mirage. How can anyone divide a memory?" (241). In the 
end,

That word 'freedom' is the great gaoler, the illusion behind countless deaths in the name of the nation... behind all those pictures of people killed by terrorists and the army is the single word 'free'. Whole villages killed so that the terrorists will be destroyed and the country made free. (Ghosh, 1988: 232)

This could be regarded as prophetic for our century.

\section{Midnight's Heirs}

There are of course many novels that have built on Rushdie's and Ghosh's scepticism, but Roy's The God of Small Things (1997), Desai's The Inheritance of Loss (2006), Adiga's The White Tiger (2008) and Kunzru's Transmission (2004) sketch the trajectory of the contemporary novel's extension of Midnight Children's subversion of the grand narrative of nation. The status of the first three as Booker prizewinners (Kunzru's novel was shortlisted) emphasizes the growing global reach of Indian literature. Stories of family and community continue, but very differently in form and orientation from the Gandhi-inspired vision of Raja Rao or R.K. Narayan. The constant tension between the Gandhian sense of community in family or village and the large, increasingly global sense of History and Nation characterize these novels in different ways. They do not highlight the growing tensions of communal violence, of Shiv Sena and Hindu majoritarianism, which form much of the interest of the 'Bombay novel' of the 1990s, but they expose the extent to which both the idea and the reality of Nation have betrayed those who so enthusiastically embraced it in 1947.

Sixteen years after Midnight's Children, Roy's The God of Small Things refuses the grandeur and epic scale of Rushdie's novel in favour of a story of small people whose lives are shattered by small things that take on an immense significance. Priyamvada Gopal states that "[after] the stylistic pyrotechnics of magical realism, Roy's novel proffered a masterly command of realism and the pleasures of seemingly unmediated experience" (2009: 156). Indian history, argues Ranajit Guha (1996: 3), is fixated on the nation-state, which determines how the past is to be read; this can be undone by listening to the myriad 'small voices' in Indian society. Roy's is a classic postcolonial approach to History, which is invariably the history of the state. Where the 'Big God' of Nation or Empire writes History, it gets in the way of memory - the grand narrative of the nation 
swallows up the smaller narratives of its people. So often it has been the task of literature to re-write History because the dominance of Imperial History so easily slides into the grand narrative of the Nation. Where 'Big God' controls the writing of official History, Small God “climbed into people's eyes and became an exasperating expression" (Roy, 1997: 11) If the nation is the dominant story, then individuals are subject to that story. It is in the 'small things', according to Roy, that the life of the nation is contained, and it is by reading the silences in the interstices of the grand narrative of History that the stories that make up the nation can be recovered.

Kiran Desai's The Inheritance of Loss (2006) circulates around the pathos of those discarded by History, those out of time and place, whether the anglophile remnants of a faded empire or those caught out of place by the desire to better their lives in the West. The 'loss' inherited is the loss of empire, of privilege, of home and also of the sense of place bestowed by the idea of nation. "Could fulfilment ever be felt as deeply as loss?" (Desai, 2006: 2), asks the novel as it questions the possibility of fulfilment in the constantly shifting realities of nation and history. Set in the Himalayan region of the India/Nepal border and illuminating the debilitating state of displacement experienced by wealthy anglophile Indians as the region is torn apart by a 'Gorkhaland' nationalist movement, the novel touches on the inevitability and the inevitable futility of nationalism. It contrasts this with the desperate straits of the cook's son Biju, in New York without a green card, who demonstrates a different state of loss, as he gradually loses his dream of wealth in the harsh reality of the exploited illegal immigrant. The novel hinges on the uncertainty of liminal spaces - the geographical liminality of those on the borders of the nation, the liminality of those who have been betrayed by history, the liminality of the immigrant worker.

Aravind Adiga's searingly iconoclastic novel The White Tiger (2008) raised considerable controversy when it was published for its unflattering view of Indian society. Nonetheless, it continues an approach to the corruption of politics and the 'democratic state' that lies deep in the Indian social consciousness. Adiga's mantra, "to be a man", is at no great distance from Gandhi's philosophy of satyagraha, although the language the novelist uses to attack the failed democratic nation is far more trenchant, a savage critique of the corruption of capitalist society. The putative address of the novel to Wen Jiabao 
places the novel in a global context from the first line. Though it enables an informal insouciant style, its globalizing trajectory also permits a considerable degree of dramatic irony in the voice of the 'white tiger' as he continually compares the Indian economic reconstruction to the Chinese: "And these entrepreneurs - we entrepreneurs - have set up all these outsourcing companies that virtually run America now." (Adiga, 2008: 4). The White Tiger is the novel of an India that has unquestionably taken its place in the world. But here the silences of the 'small things' overwritten by history find an ironic revenge as Balram enters the entrepreneurial future through murder, theft and bribery.

A novel that did not receive a Booker Prize but nonetheless reveals the global trajectory of Indian writing perhaps better than any other is Hari Kunzru's Transmission. Including this novel within this company raises a significant question: What is an "Indian" novel today? Hari Mohan Nath Kunzru was born in London of Kashmiri Pandit origin. Sometimes referred to as a 'British Indian' novelist, and deputy president of English PEN, he, along with fellow writers Ruchir Joshi, Jeet Thayil and Amitava Kumar, risked arrest by reading out excerpts from Rushdie's The Satanic Verses (which is banned in India) at the 2012 Jaipur Literature Festival. Thus, by orientation, commitment, and, in Transmission, by subject-matter, Kunzru is deeply implicated in the widening production of Indian writing. The question: "What is an Indian writer?" may never be conclusively answered. So many Indian novels are now written in the diaspora that it seems that Tagore's admonition about the world has been fulfilled with a vengeance, with writers' national identities becoming more and more a matter of representation.

If Balram Halwai in The White Tiger moves out of his life of poverty into the Bangalore milieu of 'the entrepreneur,' Transmission's hero Arjun Mehta extends this movement into the Californian Silicon Valley Nirvana of every middle-class computer nerd. Arjun, a geeky, daydreaming Indian software engineer, fares little better, at first, than the impoverished Biju in Inheritance of Loss. He is recruited by an exploitative staffing agency to work in Silicon Valley, "the daydream location, a hidden ravine lined with fibre optics and RadioShacks" (Kunzru, 2004: 22). He is employed as a specialist in virus protection, but when he is unfairly laid off he creates the Leela virus (based on his film idol Leela Zahir), a virus so sinister that only he will be able to find the cure, thus making him an indispensable employee. When his company refuses to re-employ him, systems 
around the globe suddenly become infected and inoperable, with a mysterious rendering of Leela Zahir dancing across the screen. However, Arjun's plot is uncovered by the FBI and simple, day-dreamy Arjun becomes the world's most-wanted terrorist. In a classic Bollywood conclusion the film star Leela Zahir, herself unhappily exploited by her mother's ambition, disappears after viewing a message Arjun has sent her. We are not told, but can certainly assume that Leela has run off with Arjun: "Like Arjun Mehta, Leela Zahir has never reappeared" (271) - a dénouement which emphasizes the complex and confusing integration of the virtual and the 'real' in the modern world.

\section{The Legacy: Class, Nation, World}

Gandhi's vision of Hind Swaraj is one of the most potent forms of utopianism of modern times, and was, as we have seen, a very different vision of 'home rule' from that perceived by most politicians. Hind Swaraj is interesting because it was able to achieve what Frantz Fanon thought nationalism could not do: mobilize the "innermost hopes of a whole people" (Fanon, 1963: 148). It is arguable that Nehru's modern industrial socialist nation could not have been established without the utopia of Hind Swaraj. Yet paradoxically this vision, so critical in the birth of Indian nationalism was anti-nationalist, anti-Enlightenment and anti-modern. Indeed Gandhi's vision of Hind Swaraj was as far from the modern capitalist state as could be imagined. 'Home rule' conceived an India outside any version of the modern nation state - an India much closer to Ernst Bloch's conception of Heimat than to the modern idea of nation (as indeed was Tagore's). Heimat is Bloch's word for the home that we have all sensed but have never experienced or known. It is Heimat as utopia that "determines the truth content of a work of art." (Zipes, 1989: xxxiii). This paradox is explored in Partha Chatterjee's foundational study Nationalist Thought and the Colonial World (1986), which exposes the ambivalent relationship between utopian thinking and nation-building and the actual process by which utopian thinking may evolve, or 'degenerate,' into an organised nation-state machine.

However, when we examine the extent to which the post-Rushdie novel continues the resistance to the idea of the nation state, three themes appear. The first is the continuation in different ways of the condemnation of class and economic injustice. In Gandhi this was 
most prominent in his condemnation of untouchability, but the philosophy of Khadi or self-sufficiency was at the same time a programme of economic equality and a critique of capitalism. Second is the critique of the bounded nation state itself, a critique that blossoms in Indian writing in the metaphor of borders, and continues the spirit of both Tagore's and Gandhi's anti-state philosophies. The third characteristic of the contemporary novel is its movement outward from 'Home' into the 'World'. Both the actual mobility of writers and the exogenous way Indian consciousness interpolates the economic, cultural and literary world in the novels considered here suggest a trajectory that will continue into the twenty-first century.

\section{Class}

The theme of class is summed up in The White Tiger when Balram says in his letter to Wen Jiabao: "I won't be saying anything new if I say that the history of the world is a history of a ten thousand year war of brains between the rich and the poor." (Adiga, 2008: 254). It is significant that the war is described as one of brains, but it is nonetheless one in which the structure of the contest is heavily weighted against the poor.

Despite Arundhati Roy's very well-known activism and her radical interest in class struggle, her distinction between the 'small God' and the 'Big God' is a subtle one in which class overlaps nation, as private and personal despair drops below the gaze of the public or citizenship or the nation:

In some places, like the country that Rahel came from, various kinds of despair competed for primacy. And the personal despair could never be enough. That something happened when personal turmoil dropped by the wayside shrine of the vast, violent circling, driving, ridiculous, insane, unfeasible, public turmoil of a nation. That Big God howled like a hot wind and demanded obeisance. Then Small God (cozy and contained, private and limited came away cauterized, laughing numbly at his own temerity. (Roy, 1997: 19)

The Small God is the God of the impoverished and disenfranchised, but it is also the God of the teeming ordinariness of the people living beneath the level of the grand narrative of nation. Where Big God controls the writing of official History, Small God "climbed into people's eyes and became an exasperating expression" (Roy, 1997: 19). If the nation is the dominant story then the ordinary individual stories are footnotes, and individual despair does not enter the story.

In each of these novels the issues of class, of poverty, of abandonment by corrupt 
officials are inextricable from the failure of nation. In Tagore's words, "the Nation is the greatest evil for the Nation" (2005: 60). However, this failure is just as often a consequence of nationalism. In The Inheritance of Loss the pathos is maintained by the confusion of those caught in a changing world in which their privilege is diminishing under the onslaught of demands for justice and independence. The sisters Lola and Noni find themselves "with the rotten luck of being in the exact wrong place at the exact wrong time when it all caught up - and generations worth of trouble settled on them" (241). The achievement of the novel is to reveal the extent to which issues of class, privilege and discrimination occur as a function of the structure of the postcolonial nation fuelled more by ignorance than by active discrimination. Lola and Noni are the recipients of the privilege bestowed by empire. Now the Nepali inhabitants of this border region are demanding change.

The obnoxious judge whose anglophilia is so rampant that he functions as a cultural metaphor in the book is driven by hatred for everything - his wife, daughter, cook, India and probably subconsciously himself for his abjection to imperial power. As a Cambridge student he had undertaken with utter resolve to become as English as he could, only to be despised by both his countrymen and his colonial masters. It is not until the moment of independence that he realizes this:

He thought of how the English government and its civil servants had sailed away, throwing their topis overboard, leaving behind only those ridiculous Indians who couldn't rid themselves of what they'd broken their souls to learn. (Desai, 2006: 205)

It is perhaps this more than anything: the feeling of being thrown on the dust-heap of history, of being betrayed by imperialism, that generates the judge's rage. This is why he decides to live in the hills, at the very edge of the nation: "The judge could live here, in this shell [of a house] this skull, with the solace of being a foreigner in his own country, for this time he would not learn the language." (Desai, 2006: 29) His determined alienation from everything and everyone except his dog Mutt reveals the true absurdity of his position as the detritus of empire. When his dog is stolen his entreaties seem laughable to people who are starving.

The issue of class (and caste) is deeply bound up in The White Tiger with that of social and political corruption. Gandhi waged a lifelong war against untouchability, claiming 
that there was nothing in the Shastras justifying it (CWMG 62: 121-22, 16 November 1935). However, it is class that seems to have taken a greater hold on the contemporary literary imagination. Balram sees caste as meaningless rather than constricting. A member of the Halwai caste of sweetmakers, he knows nobody in his family who made sweets. His father was a rickshaw driver. Caste is overshadowed in the novel by the spectre of economic class and poverty, particularly the poverty of those at the very bottom of society. This is perhaps nowhere clearer than in the corruption of the health system. Balram's father, dying of TB, waiting at a hospital to which no doctor will visit, is 'permanently cured' of his TB at 6pm that night "as the government ledger no doubt accurately reported" - by dying (Adiga, 2008: 50) The doctors, by bribing the supervisor, were marked as present and released to earn money in private practice.

The poor are not only subject to the corruption of the system. They dwell completely outside the political process. Balram is regarded with scorn by his employers, who see his ignorance as disqualifying him from political enfranchisement. When asked questions such as 'Who was the first Prime Minister of India? What is the name of this continent? Balram's apparently risible answers lead him to remark: "And we entrust our glorious parliamentary democracy - he pointed at me - to characters like these. That's the whole tragedy of this country." (10) Consequently, (in a poignant echo of Rohinton Mistry), everybody's vote in Balram's village is controlled by the landlord. When a "brave mad man" turns up to the voting booth to demand to cast his vote he is beaten to death by the local politician and the police. "After a while the body of the rickshaw puller stopped wriggling and fighting back, but they kept stamping on him, until he had been stamped back into the earth." (102) Significantly, the poor are of the soil and are kept there by the system - "stamped back into the earth". This is something Gandhi himself sensed. His conception of the nation looked beyond the structure of the legislature: "What strange blindness it is that those who are elected as legislators to represent the people should seem, and in fact are, their rulers!" (CWMG 38:18, 4 November 1928). The White Tiger puts horrifying flesh to the bones of that reality. As Balram says: "I am India's most faithful voter, and I still have not seen the inside of a voting booth." (102)

It is not just from voting but from access to the amenities of society that the poor find themselves excluded. The drivers who wait outside the gleaming glass mall for their 
masters to shop are enthralled to see a rickshaw puller attempt to enter the Mall, but he is stopped by the guard. "Instead of backing off and going away - as nine in ten in his place would have done, the man in the sandals exploded, "Am I not a human being too?" (148) As one of the drivers remarks: "If all of us were like that we would rule India and they would be polishing our boots" (148-49). The problem is, of course that individuals like this are very rare and Adiga explains it with the metaphor of the Rooster Coop:

Never before in human history have so few owed so much to so many, Mr Jiabao. A handful of men in this country have trained the remaining 99.9 per cent - as strong, as talented as intelligent in every way - to exist in perpetual servitude; a servitude so strong that you can put the key of his emancipation in a man's hands and he will throw it back at you with a curse. (175-76)

The Rooster Coop does its work when servants keep other servants "from becoming innovators, experimenters or entrepreneurs" (194). However extreme and hyperbolic we regard The White Tiger it is worth remembering that Gandhi regarded economic equality as the "master-key to non-violent independence":

Working for economic equality means abolishing the eternal conflict between capital and labour. It means the levelling down of the few rich in whose hands is concentrated the bulk of the nation's wealth on the one hand, and the levelling up of the semi-starved naked millions on the other. A non-violent system of government is clearly impossibility so long as the wide gulf between the rich and the hungry millions persists. (CWMG 81: 366, 13 December 1941)

A subtle issue in the question of class is education, for economic equality relies not only on the levelling of wealth but on the education of the poor. As Balram discovers, the reading matter of choice for the drivers is Murder Weekly, which acts as a form of social control, because "the murderer in the magazine is so mentally disturbed and sexually deranged that not one reader would want to be like him ... So if your driver is busy flicking through the pages of Murder Weekly, relax. No danger to you. Quite the contrary. It's when your driver starts to read about Gandhi and the Buddha that it's time to wet your pants Mr Jiabao". (Adiga, 2008: 126) 


\section{The Nation and its borders}

Nation has been crucial to decolonizing rhetoric. The pre-independence utopia of a liberated postcolonial nation provided a very clear focus for anti-colonial activism in India, but this ground to a halt once the goal of that activism was reached and the sombre realities of post-independence political life began to be felt. Both Tagore and Gandhi saw the issues of class and economic disparity as being tied up with the problem of the nation state and its promotion of profit. In one of his more resonant visions of unmet possibility Tagore says:

The conflict between the individual and the state, labour and capital, the man and the woman; the conflict between the greed of material gain and the spiritual life of man, the organized selfishness of nations and the higher ideals of humanity; the conflict between all the ugly complexities inseparable from giant organizations of commerce and state and the natural instincts of man crying for simplicity and beauty and fullness of leisure - all these have yet to be brought into harmony in a manner not yet dreamt of. (Tagore, 2005: 7)

The core of the problem was the inheritance of colonial boundaries, colonial administrative structures, and colonial prejudices, so that the problem of the Nation was from the beginning a problem of borders. Part of the power of The God of Small Things comes from the vividness with which the children's impressions and voice are relayed. Childhood is a time without divisions, whereas now "Edges, Borders, Boundaries, Brinks and Limits have appeared like a team of trolls on their separate horizons" (Roy, 1997: 3). The grand narratives of Nation and History are part of this team, and Roy's apparent break from the exuberant excess of Rushdie's sweeping novel nevertheless implies a focus on similar issues - on the boundaries that hem us in all sides.

One of the most bounded dimensions, one in which the destiny of the nation is figured, is time. Time is the medium of the nation's teleological move towards completion and fulfilment. But it is a movement that never resolves itself, that is never realized and cannot ever be. One of the ways in which The God of Small Things disrupts the boundary of time is by presenting its two central stories in more or less alternating chapters - an Indian family living in Ayemenem in Kerala during a two-week period in 1969, and the murderous consequences; and the story of a day in 1993, when the twins Estha and Rahel meet for the first time since the violent events twenty-three years before, a meeting that culminates in an incestuous sexual encounter. Each chapter weaves back and forth over 
other time periods, creating a complex series of references and allusions. Repeated flashbacks and images bring past events into the present and, while future events appear to disrupt the past. Elizabeth Outka argues: "By presenting the novel's temporal framework not as a continuous narrative but as a disordered mix of various times that can be pieced together only by the reader (if at all), Roy's text echoes the way her characters are experiencing the present moment, one always already haunted by past and future events" (Outka, 2011: 25-26). This experience, like so much of the domain of the Small God, exists well below the level of Nation.

However, the nation is not always subverted in so subtle a fashion. In many respects, despite the soaring aspirations of politicians, the Nation took over the function of the colonial masters. As Balram says in The White Tiger: "In 1947 the British left, but only a moron would think we became free then" (Adiga, 2008: 22). Perhaps worse than that, the new order was a jungle:

And then, thanks to all those politicians in Delhi, on the fifteenth day of August 1947 the day the British left - the cages had been left open; and the animals had attacked and ripped each other apart and jungle law replaced zoo law. Those that were most ferocious, the hungriest, had eaten everyone else up ... (Adiga, 2008: 63-64)

Adiga's novel depends upon hyperbole, because this is the métier of Balram's discourse in his letters to Wen Jiabao. But it is clear that the triumph of the nation has become the triumph of corruption. The "Great Socialist" is the regional strongman who eventually wins the national elections, and his record is spectacular:

The Great Socialist - a total of ninety-three criminal cases - for murder, rape, grand larceny, gun-smuggling, pimping and many other such minor offences - are pending against the Great Socialist and his ministers ... and three of the ministers are currently in jail - but continue to be ministers. (97-98)

In The Inheritance of Loss the nation is just as powerful in its invisibility as in its obvious control, partly because the region is in the grip of an insurgency in which the very concept of nation is at stake. Here at the geographical edges of nation, the porous border of the state, a new nationalism rises up to demonstrate the persistence of national feeling. “This state making," says Lola, "biggest mistake that fool Nehru made. Under his rules any group of idiots can stand up demanding a new state and get it too. How many new 
ones keep appearing?” (Desai, 2006: 128).

There is an ironic moment when Gyan, coming to visit Sai, is ordered by the judge to recite poetry, to which he responds by reciting Tagore.

"Where the head is held high. Where knowledge is free, Where the world has not been broken up into fragments by narrow domestic walls... Into that heaven of freedom, my Father, let me and my country awake." Every schoolchild in India knew at least this. (Desai, 2006: 109)

This is a poignant reminder of Tagore's view of nationalism, because Gyan is becoming enmeshed in the "narrow domestic walls" of a Ghorkaland rebellion, a political passion that will destroy his love for Sai. Indeed the pathos of the novel is played out in the conflict between the justice of the Ghorkas' cry for equality, their desire for "that heaven of freedom," and the consequences of their actions. Here at the edge of the nation, in the liminal space of a porous border, a different kind of nationalism wreaks its havoc.

As he floated through the market, Gyan had a feeling of history being wrought, its wheels churning under him, for the men were behaving as if they were being featured in a documentary of war, and Gyan could not help but look on the scene already from the angle of nostalgia, the position of a revolutionary (Desai, 2006: 157)

"In 1947, brothers and sisters, the British left granting India her freedom, granting the Muslims Pakistan, granting special provisions for the scheduled castes and tribes, leaving everything taken care of brothers and sisters -

Except us. EXCEPT US.” (158)

Although the cry of freedom is strong in this liminal space of the Himalayan border, this passage reaffirms the continued dependence of postcolonial national formations on imperial structures: "The men sat unbedding their rage, learning, as everyone does in this country, at one time or another, that old hatreds are endlessly retrievable" (161). Rage, enmity, passion, the feelings of class exclusion and economic injustice, of ethnic marginalization resolve themselves inevitably in the utopia of nation. As Sai ponders: "What was a country but the idea of it? She thought of India as a concept, a hope, or a desire. How often could you attack it before it crumbled?" (236). What Sai finds herself in the middle of is the endless cycle of history, the passion for decolonization repeating itself. 


\section{The World}

It would be foolhardy to see the mobility and outward movement of Indian writing and, indeed, Indian society itself as motivated by those high cosmopolitan ideals expressed by Tagore, the "moral power of love and vision of spiritual unity". Even so, it is worth noting that the global sensibilities of the contemporary Indian novel have a deep prehistory. Certainly colonialism unleashed an unprecedented era of mobility as colonial peoples flowed to the centre and then circulated to other economic magnets. India, however, was already a migratory and even diasporic aggregation of flows and convergences, both within and without state boundaries. Jagat K. Motwani has made a compelling, if provocative, claim for the migratory adventures of Indian peoples since about $8000 \mathrm{BC}$ - migrations as far as Mexico, Turkey, Bali as well as the obvious migrations to South-East Asia (2004: 40). Motwani's investigations challenge the very profound and resilient linking of Indian identity with the geographical Bharat (the ancient term for the holy land of the Hindus), with 'Mother India'. For him the Indian people have always been migratory and exploratory, and it would seem that flow rather than stasis is a cultural characteristic.

This flow, however, is not always enriching. The other side of the story of displacement and loss in The Inheritance of Loss is the failed aspirations of those like the son of the judge's cook, Biju, whose journey to New York leads to poverty and exploitation by other Indians. Ejected from restaurant after restaurant as he looks for work, slipping "out and back on the street. It was horrible what happened to Indians abroad and nobody knew it but Indians abroad" (Desai, 2006: 138). One thing Biju discovers in New York is the extent to which a country is no more than an idea, an idea that grows more vague the further away you travel: "What was India to these people? How many lived in fake versions of their countries, in fake versions of other people's countries? Did their lives feel as unreal to them as his did to him?” (267.) Biju exists in the dystopian version of diaspora inhabited by many: without visa or green card, exploited, underpaid, sleeping on the floor of the restaurant kitchen. To him home is loss and absence - America, exile and loneliness. He knows that he represents the magical possibility of freedom and wealth to many back home - but it is an illusion. 
This has become the stereotype of the diasporic condition - absence and loss, poverty and failure. But there is another story demonstrated by Indian writers themselves, writers who have interpellated Anglophone literature. In this respect these novels can be seen to outline a trajectory towards a more self-assured engagement with the global - from the dystopian exile of Biju's life in New York, to Balram's move to Bangalore with its industries and call centres plugged into the global economy, to Arjun's move to Silicon Valley and his catastrophic revenge upon Virugenix and subsequently, the world. This pattern is not strictly chronological, as Transmission was written before Desai's and Adiga's novels, but it indicates the outward movement of Indian society, a movement that is increasingly captured by writers.

Transmission stands for the direction of the contemporary Indian novel in many ways: the complications of its authorship; its generic border crossing; its representation of the ways in which Indian expertise and Indian culture - through Bollywood and computer savvy have infiltrated the world; its confident satire of both US and global technological society even as it demonstrates an Indian familiarity with that society; its ability to balance an insider knowledge of Indian family dynamics with knowledge of the computer geek world. These qualities suggest a literature that is both deeply rooted in the Indian cultural consciousness and yet prolific in its engagement with the world.

The Mother India trope may continue to hold its grip on the Indian imagination, but a deeper and perhaps more lasting tendency is that spirit of questioning that occurs most influentially in Tagore and Gandhi. While we may be tempted to view their antimodernism as anachronistic and their moral urgings as naïve, these thinkers captured a sceptical view of the devil's pact between nation and capitalism that remains even more relevant today. In these contemporary novels that deep vein of scepticism continues: an awareness of the interrelation of 'Home and World;' the often exuberant iconoclasm of their approach to questions of nation and history; and the alertness to the potential failures of democracy and of international capitalism - all this suggests that the trajectory of the Indian novel has taken it a long way from the village. In their global reach, sophistication and social critique Indian novels continue to shape world Anglophone literature. 


\section{WORKS CITED}

Adiga, ARAVInd (2008), The White Tiger London: Atlantic

ASHCROFT, BILL (2011), "Urbanism, Mobility and Bombay: Reading the Postcolonial City" Journal Of Postcolonial Writing 47: 5 (Dec 11): 497-509

Chatterjee, Bankim Chandra (2006), Anandamath, or, The Sacred Brotherhood (trans. Julius J. Lipner) Oxford : OUP [1882]

Chatterjee, PARTha (1986), Nationalist Thought and the Colonial World Minneapolis: University of Minnesota Press

CWMG - The Collected Works of Mahatma Gandhi 1888-1948 http://www.gandhiserve.org/cwmg/cwmg.html

DESAI, KIRAN (2006) The Inheritance of Loss, Harmondsworth: Penguin

FANON, Frantz (1963), The Wretched of the Earth (trans. Constance Farrington) New York: Grove Press

FrAnCO, JEAN (1989), "The Nation as Imagined Community" in Aram Veeser, ed. The New Historicism New York: Routledge, 1989: 204-12.

Ghosh, Amitav (1988), The Shadow Lines New York: Mariner Books (Houghton and Mifflin)

Gopal, PriYAmVada (2009), The Indian English Novel: Nation, History and Narration Oxford: OUP

GuHA, RANAJit (1996), "The Small Voice of History", in Shahid Amin and Dipesh Chakrabarty (eds.) Subaltern Studies, ix Writings on South Asian History and Society Delhi: OUP: 1-12

KunZRU, HARI (2004), Transmission, Harmondsworth: Penguin

Motwani, Jagat K. (2004) "Indian Migratory Adverntures: Global and Ancient" in Adesh Pal and Tapas Chakrabarty (eds) Theorizing and Critiquing Indian Diaspora New Delhi: Creative Books: 39-68

MukherJee, MeEnaKshi (2006), "Maps and Mirrors: Co-ordinates of Meaning in The Shadow Lines" in Amitav Ghosh The Shadow Lines (novel and commentary) Oxford: OUP: $255-267$

OutKa, ElizABETH (2011) "Trauma and Temporal Hybridity in Arundhati Roy's The God of Small Things" Contemporary Literature 52, 1

Roy, ARUNDhATI (1997) The God of Small Things London: Harper Collins

Rushdie, SALMAN (1981), Midnight's Children London: Picador

Rushdie, Salman (1991) Imaginary Homelands: Essays and Criticism 1981-1991. London: Granta,

Tagore, Rabindranath (1999), The Home and the World [Bengali Ghare Bhaire] (trans, Surendranath Tagore) New Delhi: Penguin 
TAgore, Rabindranath (2005) Nationalism Delhi: Rupa and Co.

WASSEF, HIND (1998), "Beyond the Divide: History and National Boundaries in the Work of Amitav Ghosh", Alif 18 (1998) pp. 75-95

ZIPES, JACK (1989) "Introduction: Toward a Realization of Anticipatory Illumination" Ernst Bloch, The Utopian Function of Art and Literature: Selected Essays, trans. Jack Zipes and Frank Mecklenburg Minneapolis: University of Minnesota Press. 